\begin{tabular}{|c|c|}
\hline$\overline{\bar{z}}$ & $\begin{array}{c}\text { International Journal of Current Research } \\
\text { and Academic Review }\end{array}$ \\
\hline & $\begin{array}{c}\text { ISSN: 2347-3215 (Online),; Volume } 5 \\
\text { Journal homepage: http://www.ijcramber.com } 7 \text { (July-2017) } \\
\end{array}$ \\
\hline
\end{tabular}

doi: https://doi.org/10.20546/ijcrar.2017.507.008

\title{
The Effect of Ivabradine on High Sensitivity C-Reactive Protein Levels and Short Term Clinical Outcome in Patients with Acute Coronary Syndrome
}

\author{
Mathew George ${ }^{1}$, Lincy Joseph ${ }^{2}$ and Anumol Joseph ${ }^{2 *}$ \\ ${ }^{1}$ Department of Pharmacology, Pushpagiri College of Pharmacy, Thiruvalla-689107, Kerala, India \\ ${ }^{2}$ Department of Pharmacuetical Chemistry, Pushpagiri College of Pharmacy, Thiruvalla-689107, Kerala, India \\ *Corresponding author
}

\begin{abstract}
Acute coronary syndrome (ACS) refers to any group of clinical symptoms compatible with acute myocardial ischemia and includes unstable angina (UA), non ST-segment elevation myocardial infarction (NSTEMI), and ST-segment elevation myocardial infarction (STEMI). Ivabradine is a new bradycardiac agent acting on the $\mathrm{I}_{\mathrm{f}}$ current channels of sinoatrial nodal cells to decrease the rate of diastolic depolarization and thus the heart rate. The primary and principal cause of acute coronary syndrome in more than $90 \%$ of the patients is the rupture of an atheromatus plaque, endothelial dysfunction and inflammation and formation of fatty streaks are the core distributors to atherosclerotic plaque formation. High Sensitivity C-reactive protein is a sensitive marker of inflammation. Increased levels of Hs-CRP are associated with endothelial dysfunction, vascular inflammation and in increase cardiovascular risk. The study $(n=80)$ aims to evaluate the effect of Ivabradine on high sensitivity C-reactive protein levels and its effect on ACS therapy. The objective of the study to know the effect of ivabrdine of hs-CRP level and the assessment of cardiac risk. In the study of 80 patients, the patients was categorized into two groups, there is significant reduction of hs-CRP levels, but more significant in the group who is taking Ivabradine. Since P value is less than 0.001, in both groups the level of hs-CRP is significantly reduced. Since $\mathrm{P}>0.05$ at admission there is no significant difference in the mean value of hsCRP in both the groups. But after discharge the mean values is significantly different $(\mathrm{P}<0.05)$ and is concluded that the difference is more in GROUP 1 who is taking ivabradine.
\end{abstract}

Article Info

Accepted: 02 July 2017

Available Online: 20 July 2017

Keywords

ACS, hs-C-reactive protein,

Ivabradine, Heart rate, $I_{F}$ current.

\section{Introduction}

The term acute coronary syndrome (ACS) refers to any group of clinical symptoms compatible with acute myocardial ischemia and includes unstable angina (UA), non-ST-segment elevation myocardial infarction (NSTEMI), and ST-segment elevation myocardial infarction (STEMI). Acute coronary syndrome is a term used to describe a range of conditions associated with sudden, reduced blood flow to the heart. Unstable angina and NSTEMI are closely related conditions: their pathophysiologic origins and clinical presentations are similar, but they differ in severity $(1,2,3,4)$. A diagnosis of NSTEMI can be made when the ischemia is sufficiently severe to cause myocardial damage that result in the release of a biomarker of myocardial necrosis into the circulation. One condition under the umbrella of acute coronary syndrome is myocardial 
infarction (heart attack) — when cell death results in damaged or destroyed heart tissue. Even when acute coronary syndrome causes no cell death, the reduced blood flow alters heart function and indicates a high risk of heart attack. Acute coronary syndrome often causes severe chest pain or discomfort ${ }^{[1]}$. It is a medical emergency that requires prompt diagnosis and care. Treatment goals include improving blood flow, treating complications and preventing future problems.

Atherosclerosis is the ongoing process of plaque formation that involves primarily the intima of large- and medium-sized arteries; the condition progresses relentlessly throughout a person's lifetime, before finally manifesting itself as an acute ischemic event. Acute coronary syndrome usually results from the build-up of fatty deposits (plaques) in and on the walls of coronary arteries, the blood vessels delivering oxygen and nutrients to heart muscles.

A high-sensitivity C-reactive protein (hs-CRP) test may be used to help evaluate an individual for risk of cardiovascular disease (CVD). It may be used in combination with a lipid profile or with other cardiac risk markers, such as a lipoprotein-associated phospholipaseA2 (Lp-PLA2) test, to provide added information about heart disease risk ${ }^{[21]}$.

The American Heart Association and U.S. Centers for Disease Control and Prevention have defined risk groups as follows:

1. Low risk: less than $1.0 \mathrm{mg} / \mathrm{L}$

2. Average risk: 1.0 to $3.0 \mathrm{mg} / \mathrm{L}$

3. High risk: above $3.0 \mathrm{mg} / \mathrm{L}$

Ivabradine was approved by the U.S. Food and Drug Administration (FDA) for the treatment of chronic $\mathrm{HF}^{[27]}$. Ivabradine is the first drug with a novel mechanism of action acting by selective inhibition of the pacemaker $I_{\mathrm{f}}$ "funny" channel, which is responsible for the autonomic capacity of the sinoatrial (SA) node. $I_{\mathrm{f}}$ current are upregulated in atrial tissue of patients with HF.

\section{Materials and Methods}

Study design: A Prospective experimental study

Study population: Patient diagnosed with Acute Coronary Syndrome in cardiac IP Department

\section{Study site}

1. Department of Cardiology, Pushpagiri Medical College Hospital, Tiruvalla.

\section{Pushpagiri College Of Pharmacy, Tiruvalla}

\section{Study period: 6 MONTHS}

Sample size of the study: 80 patients.

$\mathrm{N}=\left[2 \mathrm{~S}_{\mathrm{P}}^{2}\left[\mathrm{Z}_{1-\alpha / 2}+\mathrm{Z}_{1-\beta}\right]^{2}\right] / \mu_{\mathrm{d}}^{2}$

$\mathrm{S}_{\mathrm{P}}{ }^{2}=\mathrm{S}_{1}{ }^{2}+\mathrm{S}_{2}^{2} / 2$

Where,

$\mathrm{S}_{1}^{2}$ - Standard deviation in the first group.

$\mathrm{S}_{2}{ }^{2}$-Standard deviation in the second group.

$\mu^{2}{ }_{d}$ - Mean difference between the samples.

$\alpha$-Significance level.

$1-\beta$-Power

\section{Study criteria}

\section{Inclusion criteria}

1. Patients with ischemic manifestations suspected to represent ACS.

2. Patients with sinus rhythm whose heart rate was greater than $60 \mathrm{bpm}$ on a resting standard 12 lead ECG.

3. Patients with acute ST segment elevation or non ST segment elevation Myocardial infarction.

4. Patients who are willing to sign the informed consent.

5. Patients of IP patients.

6. Patients of age $>18$ yrs.

\section{Exclusion criteria}

1. Pregnant and breastfeeding women or women of childbearing potential.

2. Patient with atrial fibrillation or flutter, sino atrial block and complete atrio ventricular block.

3. Patient who are not willing to sign informed consent.

4. Patients already on medications with ivabradine 
A Prospective experimental study was conducted at Pushpagiri Medical College hospital based on the topic "Effect of Ivabradine on high sensitivity c-reactive protein levels and short term clinical outcome in patients with acute coronary syndrome". 80 patients was selected for the study (2). The selection was based on the inclusion and exclusion criteria. Initially the baseline hsCRP was taken within 24 hours of admission (before starting ivabradine therapy). The second value of hs-CRP was taken at the time of discharge and it is then followed-up after 4 weeks. The hs-C-reactive protein concentrations were calculated using semiautoanalyser. Morisky medication adherence scale [MMAS] was used to determine the medication adherence (7).

Instrument: Semi autoanalyser.

\section{Reagent used}

Diluent (R1): Tris buffer 20mmol/1, pH 8.2 Sodium azide $0.95 \mathrm{~g} / \mathrm{L}$.

Latex (R2): Latex particles coated with goat IgG antihuman CRP, pH 7.3, Sodium azide $0.95 \mathrm{~g} / \mathrm{L}$.

\section{Determination of hs-CRP}

Preparation of blank: Add $10 \mu \mathrm{l}$ of calibrator solution into a test tube

Preparation of standard: Add diluent (R1) $0.8 \mathrm{ml}$ and latex (R2) $0.2 \mathrm{ml}$ into a test tube.

Preparation of test: Add diluent (R1) $0.8 \mathrm{ml}$ and serum $0.2 \mathrm{ml}$ into a test-tube, Mix and read the absorbance after $4 \mathrm{~min}$

\section{Results and Discussion}

In this study, most of the study population falls under the age group 45-79. The patients mostly found in between the age group of 55-70. Out of the 80 patients in this study, majority of ACS patients were males $(67.5 \%)$ and remaining were females $(32.5 \%)$.

Among the 80 enrolled patients in the study, 93.8\% patients were married and $6.3 \%$ were unmarried. It was observed that only $17.5 \%$ patients are having a positive family history and $82.5 \%$ were free of risk.

When considering the Educational status of 80 patients, $70 \%$ patients were educated, nearly $30 \%$ were uneducated, $65.0 \%$ were employed and $35 \%$ were unemployed.

Out of the 80 patients, $8.8 \%$ were having a co-morbidity of heart failure, $73.8 \%$ were having a co-morbidity of peripheral arterial disease, 5\% were having chronic renal failure, $10.0 \%$ were having pulmonary disease, $2.5 \%$ were having GIT disorders.

From the total of 80 patients considered in the study, the main cause of acute coronary syndrome was due to hypertension (52.5\%), dyslipidemic conditions(46.3\%) and diabetic conditions (47.5\%) followed by smoking $(26.3 \%)$, obesity $(31.3 \%)$, oldage $(27.5 \%)$.

ADR of Ivabradine when evaluated using narinjo scale of adverse drug reaction, ADR, it is found to be unlikely (76.3\%).From the study, it was clear that patient counselling had improved the medication adherence as the $\mathrm{P}$ value is less than 0.001 after couselling.MMAS- 4 scale was used for medication adherence

Table.1 Distribution of patients based on ADR

\begin{tabular}{|c|c|c|c|}
\hline ADR & GROUP 1 & GROUP 2 & Total \\
\hline \multirow{2}{*}{ Unlikely } & 29 & 32 & 61 \\
\cline { 2 - 4 } & $36.3 \%$ & $40.0 \%$ & $76.3 \%$ \\
\hline \multirow{2}{*}{ Possible } & 11 & 8 & 19 \\
\cline { 2 - 4 } & $13.8 \%$ & $10.0 \%$ & $23.8 \%$ \\
\hline \multirow{2}{*}{ Probable } & 0 & 0 & 0 \\
\cline { 2 - 4 } & $0.0 \%$ & $0.0 \%$ & $0.0 \%$ \\
\hline \multirow{2}{*}{ Definite } & 0 & 0 & 0 \\
\cline { 2 - 4 } & $0.0 \%$ & $0.0 \%$ & $0.0 \%$ \\
\hline \multirow{2}{*}{ Total } & $\mathbf{4 0}$ & $\mathbf{4 0}$ & $\mathbf{8 0}$ \\
\cline { 2 - 4 } & $\mathbf{5 0 . 0 \%}$ & $\mathbf{5 0 . 0 \%}$ & $\mathbf{1 0 0 . 0 \%}$ \\
\hline
\end{tabular}


Table.2 Distribution of patients based on ACS co-morbidities

\begin{tabular}{|c|c|c|c|c|}
\hline \multicolumn{2}{|c|}{ ACS CO-MORBIDITIES } & GROUP 1 & GROUP 2 & Total \\
\hline \multirow{2}{*}{ Heart failure } & Count & 4 & 3 & 7 \\
\cline { 2 - 5 } & \% of Total & $5.0 \%$ & $3.8 \%$ & $8.8 \%$ \\
\hline \multirow{2}{*}{ Peripheral arterial disease } & Count & 29 & 30 & 59 \\
\cline { 2 - 5 } & \% of Total & $36.3 \%$ & $37.5 \%$ & $73.8 \%$ \\
\hline \multirow{2}{*}{ Chronic renal failure } & Count & 2 & 2 & 4 \\
\cline { 2 - 5 } & \% of Total & $2.5 \%$ & $2.5 \%$ & $5.0 \%$ \\
\hline \multirow{2}{*}{ Pulmonary disease } & Count & 5 & 3 & 8 \\
\cline { 2 - 5 } & \% of Total & $6.3 \%$ & $3.8 \%$ & $10.0 \%$ \\
\hline \multirow{2}{*}{ GIT disorders } & Count & 0 & 2 & 2 \\
\cline { 2 - 5 } & \% of Total & $0.0 \%$ & $2.5 \%$ & $2.5 \%$ \\
\hline \multirow{2}{*}{ Total } & Count & $\mathbf{4 0}$ & $\mathbf{4 0}$ & $\mathbf{8 0}$ \\
\cline { 2 - 5 } & \% of Total & $\mathbf{5 0 . 0 \%}$ & $\mathbf{5 0 . 0 \%}$ & $\mathbf{1 0 0 . 0 \%}$ \\
\hline
\end{tabular}

Table.3 Distribution of patients based on aetiology

\begin{tabular}{|c|c|c|c|c|}
\hline \multicolumn{2}{|c|}{ AETIOLOGY [CAUSES] } & GROUP 1 & GROUP 2 & Total \\
\hline \multirow{2}{*}{ Hypertension } & Count & 22 & 20 & 42 \\
\cline { 2 - 5 } & $\%$ of Total & $27.5 \%$ & $25.0 \%$ & $52.5 \%$ \\
\hline \multirow{2}{*}{ Diabeties Mellitus } & Count & 25 & 13 & 38 \\
\cline { 2 - 5 } & $\%$ of Total & $31.3 \%$ & $16.3 \%$ & $47.5 \%$ \\
\hline \multirow{2}{*}{ Smoking } & Count & 10 & 11 & 21 \\
\cline { 2 - 5 } & $\%$ of Total & $12.5 \%$ & $13.8 \%$ & $26.3 \%$ \\
\hline \multirow{2}{*}{ Dyslipidemia } & Count & 15 & 22 & 37 \\
\cline { 2 - 5 } & $\%$ of Total & $18.8 \%$ & $27.5 \%$ & $46.3 \%$ \\
\hline \multirow{2}{*}{ Obesity } & Count & 15 & 10 & 25 \\
\cline { 2 - 5 } & $\%$ of Total & $18.8 \%$ & $12.5 \%$ & $31.3 \%$ \\
\hline \multirow{2}{*}{ Positive Family History } & Count & 6 & 7 & 13 \\
\hline \multirow{2}{*}{ Atherosclerosis } & \% of Total & $7.5 \%$ & $8.8 \%$ & $16.3 \%$ \\
\hline \multirow{2}{*}{ Oldage } & Count & 17 & 10 & 27 \\
\hline \multirow{2}{*}{ Unhealthydiet } & Count Tolal & $21.3 \%$ & $12.5 \%$ & $33.8 \%$ \\
\cline { 2 - 5 } & $\%$ of Total & 11 & 11 & 22 \\
\hline & Count & 4 & $13.8 \%$ & $27.5 \%$ \\
\hline & $\%$ of Total & $5.0 \%$ & $0.0 \%$ & $5.0 \%$ \\
\hline
\end{tabular}

Table.4 Effect of ACS patient on heart rate

\begin{tabular}{|c|c|c|c|c|}
\hline \multicolumn{2}{|c|}{ HEART RATE >60 bpm } & GROUP 1 & GROUP 2 & Total \\
\hline \multirow{2}{*}{ Yes } & Count & 26 & 25 & 51 \\
\cline { 2 - 5 } & \% of Total & $32.5 \%$ & $31.3 \%$ & $63.8 \%$ \\
\hline \multirow{2}{*}{ No } & Count & 14 & 15 & 29 \\
\cline { 2 - 5 } & \% of Total & $17.5 \%$ & $18.8 \%$ & $36.3 \%$ \\
\hline \multirow{2}{*}{ Total } & Count & $\mathbf{4 0}$ & $\mathbf{4 0}$ & $\mathbf{8 0}$ \\
\cline { 2 - 5 } & \% of Total & $\mathbf{5 0 . 0 \%}$ & $\mathbf{5 0 . 0 \%}$ & $\mathbf{1 0 0 . 0 \%}$ \\
\hline
\end{tabular}


Table.5 Effect of ACS patient on ST segment elevation

\begin{tabular}{|c|c|c|c|c|}
\hline \multicolumn{2}{|c|}{$\begin{array}{c}\text { ST SEGMENT } \\
\text { ELEVATION }\end{array}$} & GROUP 1 & GROUP 2 & Total \\
\hline \multirow{2}{*}{ STEMI } & Count & 28 & 31 & 59 \\
\cline { 2 - 5 } & $\%$ of Total & $35.0 \%$ & $38.8 \%$ & $73.8 \%$ \\
\hline \multirow{2}{*}{ NSTEMI } & Count & 12 & 9 & 21 \\
\cline { 2 - 5 } & $\%$ of Total & $15.0 \%$ & $11.3 \%$ & $26.3 \%$ \\
\hline \multirow{2}{*}{ Total } & Count & $\mathbf{4 0}$ & $\mathbf{4 0}$ & $\mathbf{8 0}$ \\
\cline { 2 - 5 } & \% of Total & $\mathbf{5 0 . 0 \%}$ & $\mathbf{5 0 . 0 \%}$ & $\mathbf{1 0 0 . 0 \%}$ \\
\hline
\end{tabular}

Table.6 Effect of ACS patient medication adherence

\begin{tabular}{|c|c|c|c|c|c|}
\hline \multirow{2}{*}{\multicolumn{2}{|c|}{$\begin{array}{l}\text { MEDICATION } \\
\text { ADHERENCE }\end{array}$}} & \multicolumn{2}{|c|}{ GROUP 1} & \multicolumn{2}{|c|}{ GROUP 2} \\
\hline & & \multirow{2}{*}{$\begin{array}{c}\text { Before } \\
3\end{array}$} & \multirow{2}{*}{$\begin{array}{c}\text { After } \\
36\end{array}$} & \multirow{2}{*}{$\frac{\text { Before }}{2}$} & \multirow{2}{*}{$\begin{array}{c}\text { After } \\
33\end{array}$} \\
\hline & Count & & & & \\
\hline nIgाI & $\%$ of Total & $3.8 \%$ & $45.0 \%$ & $2.5 \%$ & $41.3 \%$ \\
\hline \multirow{2}{*}{ Medium } & Count & 4 & 29 & 7 & 29 \\
\hline & $\%$ of Total & $5.0 \%$ & $36.3 \%$ & $8.8 \%$ & $36.3 \%$ \\
\hline \multirow{2}{*}{ Poor } & Count & 29 & 3 & 9 & 3 \\
\hline & $\%$ of Total & $36.3 \%$ & $3.8 \%$ & $11.3 \%$ & $3.8 \%$ \\
\hline \multicolumn{2}{|c|}{ Chi square } & \multicolumn{2}{|c|}{54.862} & \multicolumn{2}{|c|}{49.9} \\
\hline \multicolumn{2}{|c|}{ Pvalue } & \multicolumn{2}{|c|}{$P<0.001$} & \multicolumn{2}{|c|}{$P<0.001$} \\
\hline
\end{tabular}

Table.7 Comparison of HS-CRP level in each group

\begin{tabular}{|c|c|c|c|c|}
\hline \multirow{2}{*}{ GROUPS } & \multicolumn{3}{|c|}{ Hs-CRP LEVEL } & \multirow{2}{*}{ P value } \\
\cline { 2 - 4 } & $\begin{array}{c}\text { ADMISSION } \\
\text { (Mean } \pm \text { SD) }\end{array}$ & $\begin{array}{c}\text { DISCHARGE } \\
\text { (Mean } \pm \text { SD) }\end{array}$ & $\begin{array}{c}\text { AFTER 4 WEEKS } \\
\text { (Mean } \pm \text { SD) }\end{array}$ & \\
\hline GROUP 1 & $6.48 \pm 2.05$ & $3.80 \pm 1.30$ & $1.44 \pm 1.07$ & $\mathrm{P}<0.001$ \\
\hline GROUP 2 & $6.65 \pm 1.62$ & $4.39 \pm 1.13$ & $2.88 \pm 1.14$ & $\mathrm{P}<0.001$ \\
\hline
\end{tabular}

Table.8 Statistical comparison of HS-CRP level based on risk level

\begin{tabular}{|c|c|c|c|c|c|}
\hline GROUPS & Hs-CRP LEVEL & ADMISSION & DISCHARGE & AFTER 4 WEEKS & P value \\
\hline \multirow{3}{*}{ GROUP 1 } & Low risk & 0 & 13 & 24 & \multirow{3}{*}{$\mathrm{p}<0.001$} \\
\cline { 2 - 6 } & Avg risk & 16 & 11 & 8 & \\
\cline { 2 - 6 } & High risk & 24 & 16 & 8 & \multirow{2}{*}{$\mathrm{p}<0.001$} \\
\hline \multirow{3}{*}{ GROUP 2 } & Low risk & 7 & 2 & 16 & \\
\cline { 2 - 6 } & Avge risk & 10 & 18 & 15 & \\
\cline { 2 - 6 } & High risk & 23 & 20 & 9 & \\
\hline
\end{tabular}


Fig.1 ACS comorbidities

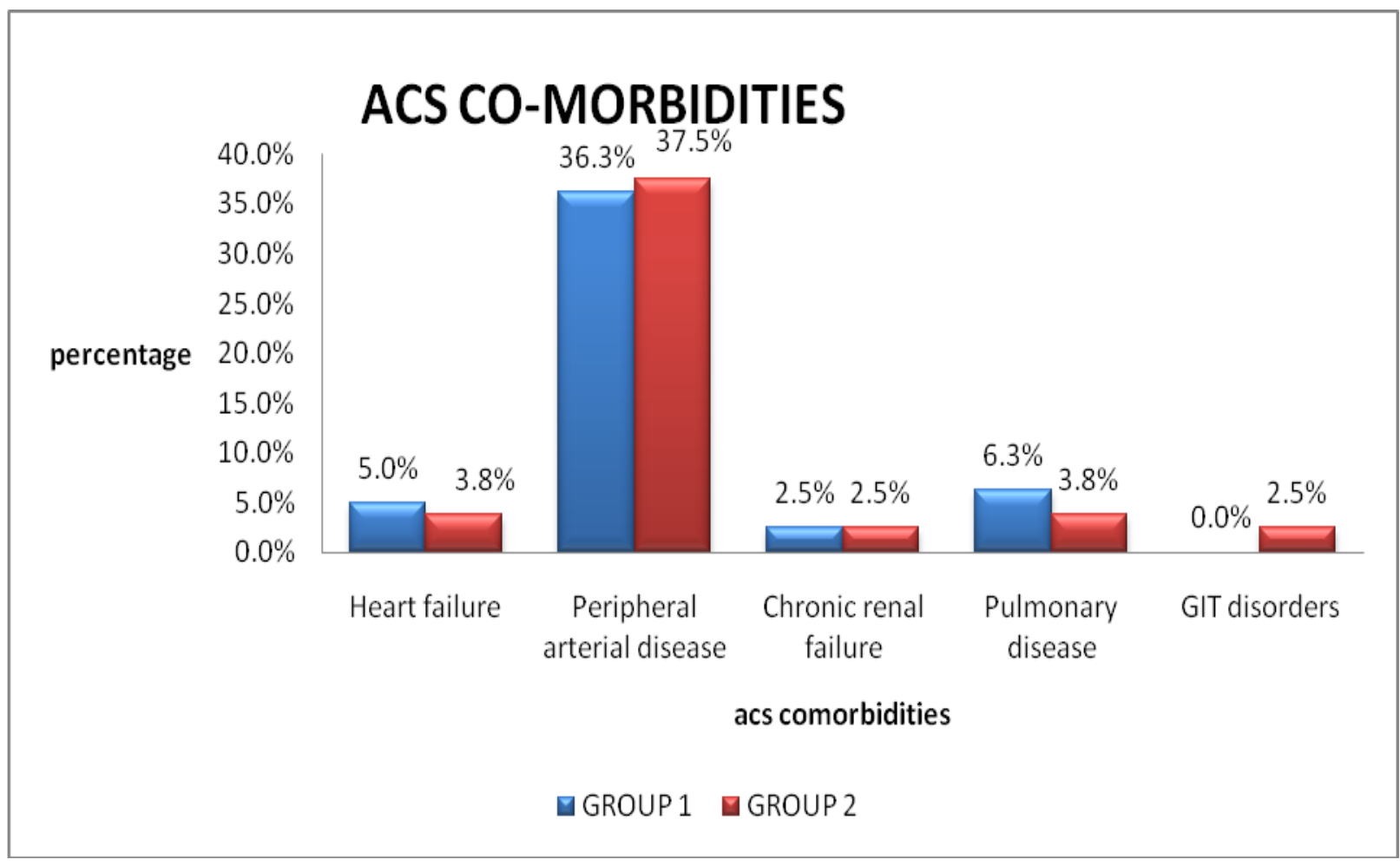

Fig.2 Etiology of ACS

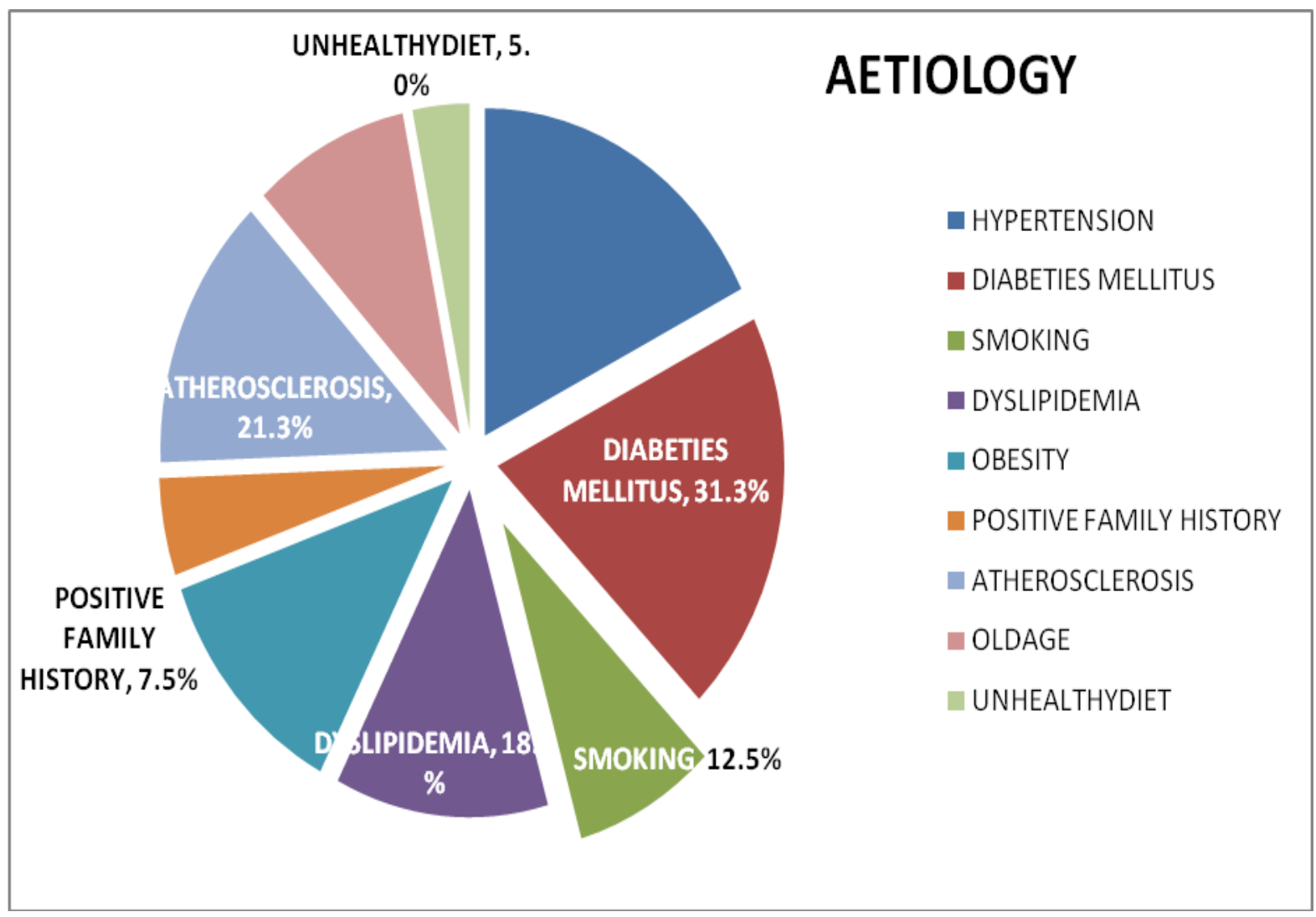


Fig.3 ADR of ACS drugs

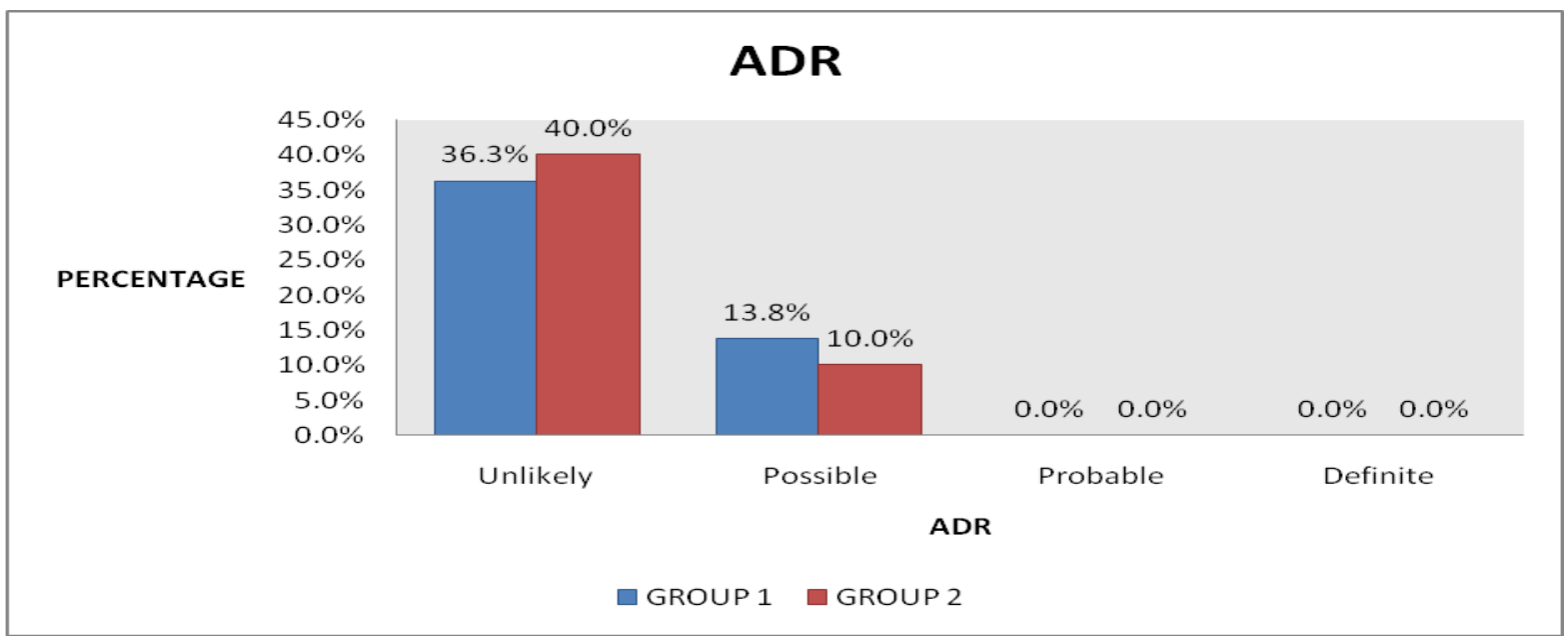

Fig.4 Medication adherence of ACS drugs

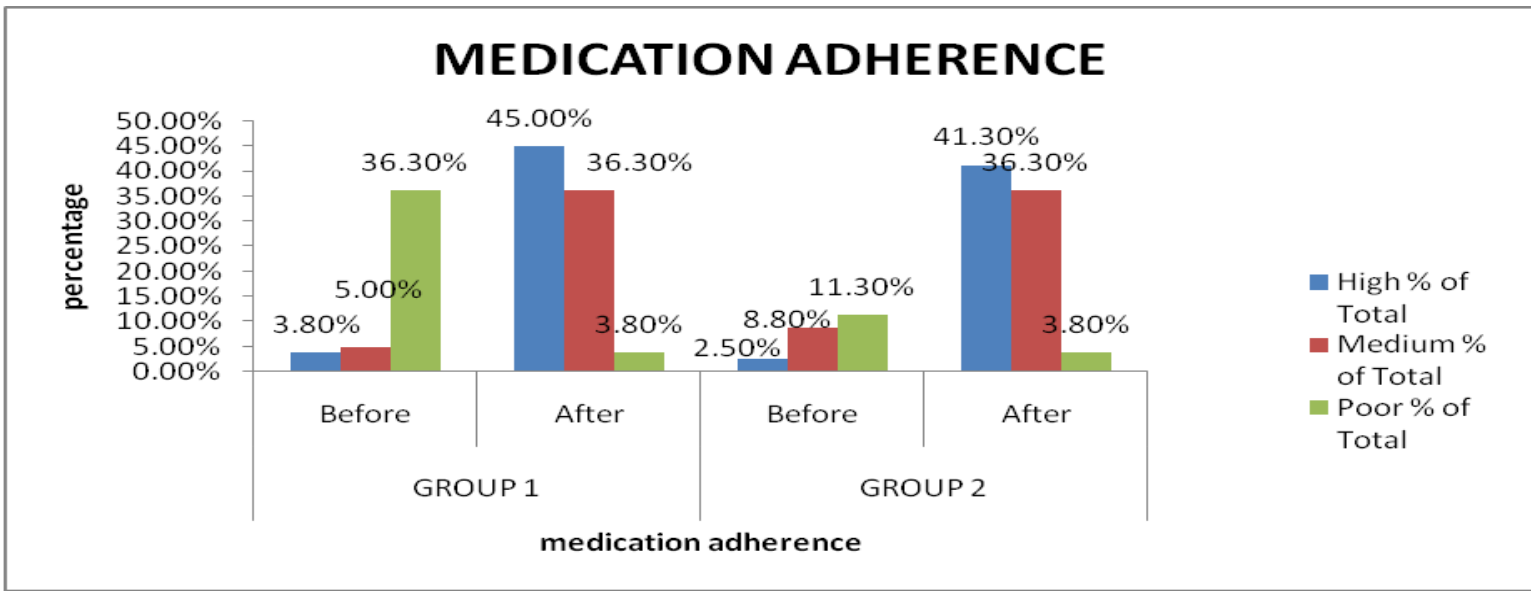

Fig.5 Effect of HS-CRP level in each groups

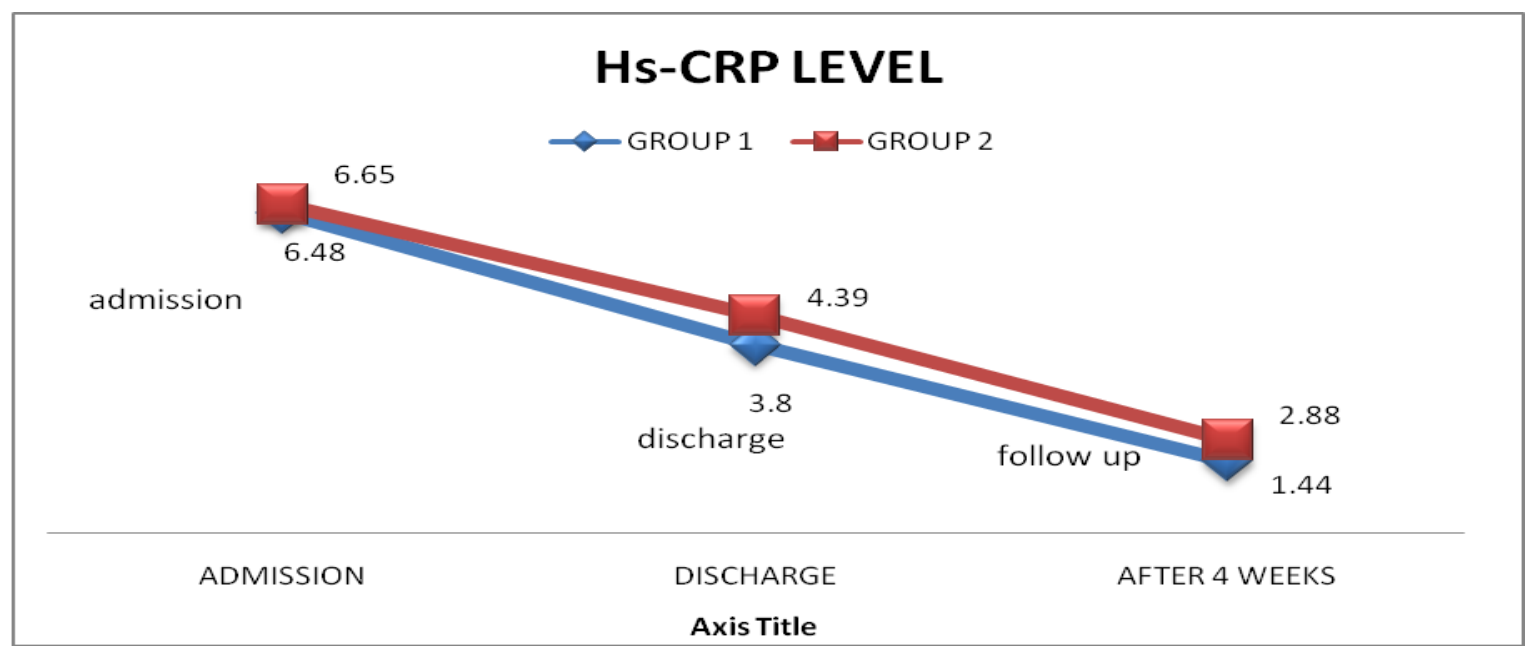

Since $\mathrm{P}$ value is less than 0.001 , in both groups the level of Hs-CRP is significantly reduced. It is found to be more significant in GROUP 1. 


\section{Effect of ivabradine on hs-crp level}

In the study of 80 patients, the patients was categorized into two groups, there was significant reduction of hsCRP levels, but more significant in the group who were taking Ivabradine. Since P value was less than 0.001 , in both groups the level of hs-CRP was significantly reduced. Since $\mathrm{P}>0.05$ at admission there is no significant difference in the mean value of hs-CRP in both the groups. But after discharge the mean values was significantly different $(\mathrm{P}<0.05)$ and it was concluded that the difference is more in GROUP 1.

Ivabradine, marketed under the trade name Corlanor among others, is a medication used for the symptomatic management of stable heart related chest pain and heart failure not fully managed by beta blockers. The patients were categorized into 2 groups. Among the two groups it was observed that the hs-CRP level was significantly reduced in those who were taking Ivabradine as the $\mathrm{p}$ value $<0.001$. Ivabradine is used to reduce the heart rate by a few beats per minute in patients with the heart condition angina. Medication adherence of Ivabradine was found to be significant in patients after counselling. Blood measurements of hs-CRP were performed to assess the risk of future heart disease. It has also been suggested that hs-CRP can be used to target therapy and tailor risk modification to prevent cardiovascular disease. Administration of ivabradine reduces the hs-crp level which gradually in turn reduces the cardiovascular risk in patients. ADR was measured using narinjo scale of adverse drug reaction.ADR was found to be unlikely with most drugs.

\section{Acknowledgement}

I am very thankful to everyone who helped and supported me to do this project and made into a success.

Conflict of interest: There is no conflict of issue with this article.

\section{References}

1. "FDA approves Corlanor to treat heart failure". www.fda.gov. Retrieved 2015-04-16.

2. Amarenco P, Labreuche J. Lipid management in the prevention of stroke: review and updated metaanalysis of statins for stroke prevention. Lancet NeUrol. 2009; 8(5): 453-463

3. Amsterdam, E. A et al., AHA/ACC Guideline for the Management of Patients with Non-ST-
Elevation Acute Coronary Syndromes: A Report of the American College of Cardiology/American Heart Association Task Force on Practice Guidelines (September 2014).

4. Australian Institute of Health and Welfare 2010. Australia's health 2010. Australia's health series no. 12. Cat. No. AUS 122. Canberra: AIHW.

5. Chew DP, Aroney CN, Aylward PE, et al., 2011 Addendum to the National Heart Foundation of Australia/Cardiac Society of Australia and New Zealand Guidelines for the Management of Acute Coronary Syndromes (ACS) 2006. Heart Lung Circ 2011; 20:487-502.

6. Huth EJ, Murray TJ, editors, eds. Medicine in Quotations: Views of Health and Disease through the Ages. 2nd ed. Philadelphia, PA: American College of Physicians; 2006.

7. Lee JK, Grace KA, Taylor AJ. Effect of a pharmacy care program on medication adherence and persistence, blood pressure, and low-density lipoprotein cholesterol: a randomized controlled trial. JAMA. 2006; 296(21): 2563-2571

8. Lewington S, Clarke R, Qizilbash N, Peto R, Collins R. Age-specific relevance of usual blood pressure to vascular mortality: a meta-analysis of individual data for one million adults in 61 prospective studies. Lancet. 2002; 360(9349): 1903-1913

9. Libby P, Theroux P. Pathophysiology of coronary artery disease. Circulation 2005; 111:3481-3488.

10. Lloyd-Jones D, Adams $R$, Carnethon $M$, et al., American Heart Association Statistics Committee and Stroke Statistics Subcommittee Heart disease and stroke statistics - 2009 update. a report from the American Heart Association Statistics Committee and Stroke Statistics Subcommittee [published correction appears in Circulation. 2009;119(3):e182] Circulation 2009

11. Mehmood Z, Naheed B, Irshad F, et al., Takotsubo cardiomyopathy: a possible metabolic disorder. Heart Metab 2014; 62: 36-40.

12. National Heart Foundation of Australia and the Cardiac Society of Australia and New Zealand (Chronic Heart Failure Guidelines Expert Writing Panel). Guidelines for the prevention, detection and management of chronic heart failure in Australia. Updated October 2011.

13. Osterberg L, Blaschke T. Adherence to medication. $N$ Engl J Med. 2005; 353(5): 487-497.

14. Rich MW, Beckham V, Wittenberg C, et al., A multidisciplinary intervention to prevent the readmission of elderly patients with congestive 
heart failure. New Eng J Med 1995; 333: 11901195.

15. Sabaté E, editor, ed. Adherence to Long-Term Therapies: Evidence for Action. Geneva, Switzerland: World Health Organization; 2003.

16. Smith SC, Jr, Allen J, Blair SN, et al., AHA/ACC guidelines for secondary prevention for patients with coronary and other atherosclerotic vascular disease: 2006 update: endorsed by the National Heart, Lung, and Blood Institute. Circulation. 2006; 113(19): 2363-2372.

17. Steiner JF, Earnest MA. The language of medication-taking. Ann Intern Med. 2000; 132(11): 926-930.

18. Stiles, Steve. "SHIFT: Adding HR-slowing agent ivabradine to HF meds cuts mortality, hospitalization". TheHeart.org. Retrieved 1 April 2011.
19. Swedberg K, Komajda M, Böhm M, Borer JS, Ford I, Dubost-Brama A, Lerebours G, Tavazzi L; on behalf of the SHIFT Investigators (2010). "Ivabradine and outcomes in chronic heart failure (SHIFT): a randomised placebo-controlled study". The Lancet. 376 (9744): 875-885. doi:10.1016/S0140-6736(10)61198-1.

20. Westert GP, Lagoe R J, Keskimaki I, et al., An international study of hospital readmissions and related utilization in Europe and the USA. Health Policy, 2002; 61: 269-278.

21. Winkler A, Teuscher AU, Mueller B, Diem P. Monitoring adherence to prescribed medication in type 2 diabetic patients treated with sulfonylureas. Swiss Med Wkly. 2002; 132(27-28): 379-385.

\section{How to cite this article:}

Mathew George, Lincy Joseph and Anumol Joseph. 2017. The Effect of Ivabradine on High Sensitivity C-Reactive Protein Levels and Short Term Clinical Outcome in Patients with Acute Coronary Syndrome.

Int.J.Curr.Res.Aca.Rev. 5(7), 52-60. doi: https://doi.org/10.20546/ijcrar.2017.507.008 